\title{
ANALYSIS OF THE COST OF PRODUCTION AND PROFIT MAXIMIZATION IN SHEEP FARMS FROM SOUTH-WEST BULGARIA
}

\author{
D. Pamukova ${ }^{1 *}$ H. Momchilov ${ }^{2}$ \\ ${ }^{1}$ Faculty of Agriculture, Trakia University, Stara Zagora, Bulagria \\ 2Faculty of Economics, Trakia University, Stara Zagora, Bulagria
}

\begin{abstract}
The purpose of this study is to compare the cost of production with purchase prices to analyze the farmers' situation in terms of the opportunities they have to sell their produce at market prices and not to lose them. The maximization of profit is based on a model of a milking sheep farm, to which all sheep farms in the same region in the analyzed region should aim. The production of forage (especially grain) in this region is limited, which is why the expenses for forage are the greatest in production for both products - milk and lamb growth. The cost analysis indicated that it was lower in some of the farms, yet close to the sale price, while in the larger portion of the farms (in all three groups), it was higher. The developed model for profit maximisation in the production of sheep's milk led us towards the following parameters: milk price of BGN 1.40 per litre and amount of produced milk between 42,000 and 45,000 litres, in which case the profit was maximal per both methods.
\end{abstract}

Key words: milk, wool, meat, marginal revenue, marginal costs

\section{INTRODUCTION}

In the EU, about $54 \%$ of the used agricultural land is classified as regions with unfavourable natural conditions. Mountain regions encompass $40 \%$ of Europe's territory and $19 \%$ of its population inhabit them. In 2006, the unfavourable regions of Bulgaria covered $55.7 \%$ of its territory, $42.8 \%$ of the agricultural land, $36.3 \%$ of arable land, and $66.2 \%$ of the uncultivated land. Compared to their structure, mountain regions occupied $88.1 \%$ of the total unfavourable region area, $83.5 \%$ of the agricultural land, $81.6 \%$ of the arable land, and $88.5 \%$ of the uncultivated land (1). These regions feel very acutely the negative consequences of climate change and extreme weather phenomena, such as draught and forest fires. They have specific features that distinguish them from the other regions in the EU - a different altitude, slope inclination, impassability, shorter periods of natural growth, lower soil quality, atmospheric and

\footnotetext{
*Correspondence to: Darina Pamukova, Faculty of Agriculture, Trakia University, Stara Zagora, Bulagria, Stara Zagora, Studentski grad, 6000 Stara Zagora, Bulagria,E-mail: dpamukova@af.uni-zs.bg; tel.number: +359887011276
}

peculiar weather phenomena, which can be considered unfavourable for the development of agriculture. The mountain regions' disadvantages make it harder for agriculture to adapt to competitive conditions and cause additional expenses, which do not allow production of competitive products with low prices. Agricultural activities in these regions (more specifically middle- and high-mountain areas) are related to investing more effort (due to the greater work requirement and necessity for hand labour) and higher expenses (due to the need for special equipment and more expensive transport) because of their natural specifics and risks. At the same time, these regions face the risk of limiting or even completely ceasing their agricultural activity, which would probably lead to changes in the landscape and the ecosystem (Resolution by the European Parliament from September 23, 2008) (2). The main production activity is the most vulnerable segment of agribusiness due to its technological and managerial limitations. Since the producers cannot control the price of their product, they have to manage their production expenses. Their economic result on a market based on competition depends on managing their production expenses and 
economies of scale (Reis et al., 2001). One of the peculiarities of agricultural produce markets is their price instability, which has increased significantly over the last few years and is expected to continue growing, in accordance to predictions by OECD and FAO (Resolution by the European Parliament from June 23, 2011) (3).

As an economic category, cost is a synonym of the average combined expenses, which include the sum of the average constant and average variable expenses and express the maintenance of production for a unit of produce (4). For producers in the field of sheep farming it is an important indicator in terms of how distant it is from the cost of a single unit of produce. Because of this, the main priority of farmers is that the produce's cost be at levels lower than the price, which would guarantee successful and efficient production.

The end goal of every producer is to derive maximum benefit from the investments they've made into production. This corresponds with the amount of the profit to be made by the venture. Maximising profit is the foundation of any production activity and is closely related to produce cost. Profit maximisation can be done in two ways: "Combined income - combined expenses" and "Marginal income - marginal expenses."

The main goal of the present study is to analyse the cost of production at sheep farms in Southwest Bulgaria, as well as offer a variant, in which the maximum level of profit for dairy production can be achieved.

\section{MATERIAL AND METHODS}

The study was conducted at 14 sheep farms in Southwest Bulgaria in the year 2018. It went through two stages. During the first, meetings were held with farmers, who filled in survey cards. The second stage featured processing of the empirical data, calculating the cost of the products and the parameters related to maximising profit in dairy production.

The farms use a pasture-shed system of animal breeding. The pasture period begins in the month of May and continues until the end of October, and the shed period - from the beginning of November to April. During the shed period, the animals are fed with meadow hay, alfalfa hay, corn and barley, while in the summer they are mainly grazing outdoors. The
PAMUKOVA D., et al.

people employed in sheep production are primarily the family members, though some farms also hire one to three additional workers. Depending on the number of kept sheep, the farms were divided into three groups: I group up to 49 ewes, II group - 50 to 99 , and III group - more than 100 ewes.

Farm incomes were formulated from the following produced and sold products:

- for the farms of group I: from the selling of lambs for meat and retired ewes, except for Farm 3 (additional income from selling milk) and Farm 5 (additional income from selling wool);

- for the farms of group II: from the selling of lambs for meat and retired ewes, except for Farm 7 (additional income from selling milk and wool);

- for the farms from group III: from milk, wool and growth.

The sheep's fertility was $100 \%$ and the milk capacity at the separate farms was within the range of $30-70$ litres. The farms produced lambs with variable live weight: $20-25$; 30-35; $35-40$ and $40-45 \mathrm{~kg}$. The following parameters were calculated: combined income (excluding subsidies), combined expenses, cost of produce, and maximising profit in the production of sheep milk. The combined income (excluding subsidies) was calculated on the base of the following buying prices: lambs for meat - BGN 5-6 for a kilogram of live weight; milk - BGN 1-1.25 per litre; and wool ranging from BGN 0.25 to BGN 1.67 per kilogram. Combined expenses are calculated as a sum of constant expenses (depreciation and pasture rent) and variable expenses (feeds, fuel, medicines, electricity, salaries and insurance).

Expenses related to animal breeding primarily include buying feeds: meadow hay - BGN 5 per stack; alfalfa hay - BGN 6-7 per stack; barley - BGN 0.25/0.27/0.30/0.32 per kilogram; corn - BGN 0.30 per kg; wheat BGN 0.20 per kg; and rye (only at Farm 11) BGN 0.40 per kg.

\section{RESULTS AND DISCUSSION}

The farms of group I had the lowest production capacity, producing and offering lambs for sale (except for Farm 3) (Table 1). 
PAMUKOVA D., et al.

Table 1. Revenue from sheep farming from the sale of production, leva

\begin{tabular}{|c|c|c|c|c|c|c|c|}
\hline \multirow[b]{3}{*}{ Sheep farming } & \multicolumn{6}{|c|}{ Revenues } & \multirow[b]{3}{*}{$\begin{array}{c}\text { Total } \\
\text { leva }\end{array}$} \\
\hline & \multicolumn{2}{|c|}{ milk } & \multicolumn{2}{|r|}{ Wool } & \multicolumn{2}{|c|}{ lambs } & \\
\hline & leva & $\begin{array}{l}\% \text { of non- } \\
\text { subsidized } \\
\text { revenue }\end{array}$ & leva & $\begin{array}{l}\% \text { of non- } \\
\text { subsidized } \\
\text { revenue }\end{array}$ & leva & $\begin{array}{l}\% \text { of non- } \\
\text { subsidized } \\
\text { revenue }\end{array}$ & \\
\hline \multicolumn{8}{|l|}{ I group - up to 49 ewes } \\
\hline Farm 1 (10 ewes) & & - & & - & 925 & 100 & 925 \\
\hline Farm 2 (20 ewes) & & - & & - & 3000 & 100 & 3000 \\
\hline Farm 3 (30 ewes) & 2488 & 45,34 & & - & 3000 & 54,66 & 5488 \\
\hline Farm 4 (40 ewes) & & - & & - & 9000 & 100 & 9000 \\
\hline Farm 5 (49 ewes) & & - & 50 & 0,94 & 5700 & 99,06 & 5750 \\
\hline \multicolumn{8}{|l|}{ II group - 50 to 99 ewes } \\
\hline Farm 6 (50 ewes) & & - & & - & 9000 & 100 & 9000 \\
\hline Farm 7 (50 ewes) & 2354 & 27,94 & 70 & 0,83 & 6000 & 71,23 & 8424 \\
\hline Farm 8 (60 ewes) & & - & & - & 6000 & 100 & 6000 \\
\hline Farm 9 (70 ewes) & & - & & - & 9500 & 100 & 9500 \\
\hline \multicolumn{8}{|c|}{ III group - more than 100 ewes } \\
\hline Farm 10 (100 ewes) & 4580 & 22,81 & 500 & 2,49 & 15000 & 74,70 & 20080 \\
\hline Farm 11 (200 ewes) & 6600 & 19,24 & 700 & 2,04 & 27000 & 78,72 & 34300 \\
\hline Farm 12 (200 ewes) & 5473 & 25,61 & 400 & 1,87 & 15500 & 72,52 & 21373 \\
\hline Farm 13 (205 ewes) & 4800 & 15,79 & 100 & 0,33 & 25500 & 83,88 & 30400 \\
\hline Farm 14 (210 ewes) & 6567 & 27,49 & 450 & 1,88 & 16875 & 70,63 & 23892 \\
\hline
\end{tabular}

In the case of Farm 3, the income from milk and lambs were relatively equal, with a difference of $9.32 \%$ in favour of lambs. Since the farm produces milk as well, the lambs are sold at a lower live weight.

In the case of Farm 5, the income was formed primarily from the sale of lambs $(99.06 \%)$. By comparison with Farm 4, the lower economic results can be explained with the lower number of ewes which gave birth (45), the larger portion of culled lambs (11\% vs. $5 \%$ for Farm 4$)$, the lower live weight at the time the lambs were sold
(30 kg vs. 40-45 kg for Farm 4), and the lower sale price.

In the farms of group II, the income was primarily from lamb population growth (except for Farm 7). The average live weight the lambs were sold at varied within $35-45 \mathrm{~kg}(35-40 \mathrm{~kg}$ in Farm 8 and $40-45 \mathrm{~kg}$ in Farms 6 and 9). In the case of Farm 7 (which produces and sells milk), it was lower $-30 \mathrm{~kg}$. Farm 8 exhibited the lowest level of income, due to the lower number of fertilised ewes.

Table 2. Costs of sheep farming by products

\begin{tabular}{|c|c|c|c|c|c|c|c|}
\hline \multirow{3}{*}{$\begin{array}{c}\text { Sheep } \\
\text { farming }\end{array}$} & \multicolumn{6}{|c|}{ Costs by products } & \multirow{3}{*}{$\begin{array}{c}\text { Total, } \\
\text { leva }\end{array}$} \\
\hline & \multicolumn{2}{|c|}{ milk } & \multicolumn{2}{|r|}{ Wool } & \multicolumn{2}{|c|}{ lambs } & \\
\hline & leva & $\%$ of costs & leva & $\%$ of costs & leva & $\%$ of costs & \\
\hline \multicolumn{8}{|c|}{ Group I - up to 49 ewes } \\
\hline Farm 1 & & - & & - & 1255 & 100 & 1255 \\
\hline Farm 2 & & - & & - & 2282 & 100 & 2282 \\
\hline Farm 3 & 2417 & 44,99 & & - & 2955 & 55,01 & 5372 \\
\hline Farm 4 & & - & & - & 3580 & 100 & 3580 \\
\hline Farm 5 & & - & 52 & 1 & 5196 & 99 & 5248 \\
\hline \multicolumn{8}{|c|}{ Group II - from 50 to 99 ewes } \\
\hline Farm 6 & & - & & - & 5502 & 100 & 5502 \\
\hline Farm 7 & 6648 & 30,67 & 199 & 0,92 & 14828 & 68,41 & 21675 \\
\hline Farm 8 & & - & & - & 5951 & 100 & 5951 \\
\hline Farm 9 & & - & & - & 10868 & 100 & 10868 \\
\hline \multicolumn{8}{|c|}{ Group III - more than 100 ewes } \\
\hline Farm 10 & 4876 & 23 & 424 & 2 & 15900 & 75 & 21200 \\
\hline Farm 11 & 10124 & 19 & 1065 & 2 & 4209 & 79 & 53282 \\
\hline Farm 12 & 4574 & 25 & 366 & 2 & 13357 & 73 & 18297 \\
\hline Farm 13 & 5047 & 16 & 315 & 1 & 26180 & 83 & 31542 \\
\hline Farm 14 & 20840 & 27 & 1544 & 2 & 54802 & 71 & 77186 \\
\hline
\end{tabular}


The farms of group III produced and sold milk alongside lamb. A larger percentage of the income at these farms is from growth (70.63 $83.88 \%$ ), and the income from milk varies within $15.79-27.49 \%$. The lambs were sold at live weight of 20-25 kg (Farms 12 and 14); 30 $\mathrm{kg}$ (Farm 11), and 35-45 kg (Farm 10).
Within the structure of the expenses, the greatest share belongs to expenses for lamb growth (Table 2). In both products, the largest relative share comes from feed expenses, as it is mostly purchased. Another factor that affects expenses (and thus cost) is the variation in the prices of some feeds (e.g. barley - varies from BGN 0.02 to 0.07 for $\mathrm{kg}$ ).

Table 3. Prime costs and sale price of products, leva

\begin{tabular}{|l|c|c|c|c|c|c|}
\hline \multirow{2}{*}{ Farms / Indicators } & \multicolumn{7}{|c|}{ Sale price (leva per kg) } & \multicolumn{2}{|c|}{ Prime costs (leva per kg) } \\
\cline { 2 - 7 } & milk & meat & wool & milk & meat & wool \\
\hline Group I - up to 49 ewes & - & 5 & - & - & 6,8 & - \\
\hline Farm 1 & - & 5 & - & - & 3,8 & - \\
\hline Farm 2 & 1,25 & 5 & - & 1,21 & 4,9 & - \\
\hline Farm 3 & - & 5,5 & - & - & 2,19 & - \\
\hline Farm 4 & - & 5 & 0,5 & - & 4,9 & 0,52 \\
\hline Farm 5 & - & 5,5 & - & - & 3,36 & - \\
\hline Group II - from 50 to 99 ewes \\
\hline Farm 6 & - & 5 & 0,58 & 2,84 & 12,82 & 1,8 \\
\hline Farm 7 & 1,1 & 5 & - & - & 4,96 & - \\
\hline Farm 8 & - & 5 & - & - & 6,29 & - \\
\hline Farm 9 & - & 5,5 & - & & \\
\hline Group III - more than 100 ewes & 1,1 & 5 & 1,67 & 1,17 & 5,3 & 2,12 \\
\hline Farm 10 & 1,1 & 6 & 1,4 & 1,69 & 9,35 & 2,13 \\
\hline Farm 11 & 1,1 & 5 & 1 & 0,99 & 4,31 & 0,92 \\
\hline Farm 12 & 1 & 5 & 0,25 & 1,05 & 5,13 & 0,79 \\
\hline Farm 13 & 1,1 & 5 & 1,02 & 3,49 & 16,23 & 3,51 \\
\hline Farm 14
\end{tabular}

Table 3 indicates that the milk-producing farms sold it for approximately the same prices (with a difference of BGN $0.10-0.15$ per litre). In most farms, the cost of the milk was greater than the sale price, which generated losses. Only two sheep farms sold their milk at higher prices, yet the difference between sale price and cost was low, which had a small effect on the increase in income, and thus profit.

The farms sold lamb meat at approximately equal prices, with a difference of BGN 0.50 to 1.00 per kilogram. In 7 of the sheep farms, the sale price was higher than the cost (Farms 2, 3, $4,5,6,8$, and 12), with the difference varying between BGN 0.04 to 3.31 per kilogram. In the rest of the farms, the expenses for a unit of produce exceeded the sale price, which was a sure indication for deteriorating economic results.

For both products, the reasons for the high cost could be explained with the animals' low productivity and the higher expenses (especially for forage), caused by the region's natural and climate conditions.
Maximising the profits from sheep's milk production

Profit maximisation was made on the basis of a sheep farm model with 300 ewes of dairy designation, with $130 \%$ fertility and various levels of milk capacity (from 70 to 160 litres), and a price for a litre of milk of BGN 1.40. The developed model would cease to be accurate even in the smallest change in the sale price for a unit of produce.

Table 4 indicates that from the perspective of the "Combined income - combined expense," as well as the "Marginal income - marginal expense" approach, the data indicates that the profit threshold is about 24,000 litres of milk per year from 300 ewes.

The data also indicate that the absolute amount of the profit is maximal (BGN 13 901) at a level of milk production between 42,000 and 45,000 litres. In this range (150 litres of milk from an ewe), the marginal expense becomes equal to the marginal income (price) of BGN 1.40 per litre.

Profit can be generated after this level of production as well, but it decreases since the marginal expense sharply rises compared to the marginal income (price), reaching up to BGN 2.42 .

Trakia Journal of Sciences, Vol. 17, Suppl. 1, 2019 
Table 4. Maximization of profit in the production of sheep's milk

PAMUKOVA D., et al.

\begin{tabular}{|c|c|c|c|c|c|c|c|c|}
\hline $\begin{array}{l}\text { Number } \\
\text { of sheep }\end{array}$ & Milk, 1 & $\begin{array}{c}\text { Amount } \\
\text { of milk }\end{array}$ & Price & Revenues & Costs & Profit & $\begin{array}{l}\text { Marginal } \\
\text { costs }\end{array}$ & $\begin{array}{l}\text { marginal } \\
\text { revenue }\end{array}$ \\
\hline \multirow[t]{2}{*}{300} & 70 & 21100 & 1,40 & 29400 & 31700 & -2300 & & \\
\hline & & & & & & & 0,63 & 1,40 \\
\hline \multirow[t]{2}{*}{300} & 80 & 24000 & 1,40 & 33600 & 33600 & 0 & & \\
\hline & & & & & & & 0,55 & 1,40 \\
\hline \multirow[t]{2}{*}{300} & 90 & 27000 & 1,40 & 37800 & 35250 & 2550 & & \\
\hline & & & & & & & 1,08 & 1,40 \\
\hline \multirow[t]{2}{*}{300} & 100 & 30000 & 1,40 & 42000 & 38480 & 3230 & & \\
\hline & & & & & & & 1,27 & 1,40 \\
\hline \multirow[t]{2}{*}{300} & 110 & 33000 & 1,40 & 46200 & 42300 & 3900 & & \\
\hline & & & & & & & 0,23 & 1,40 \\
\hline \multirow[t]{2}{*}{300} & 120 & 36000 & 1,40 & 50400 & 43000 & 7400 & & \\
\hline & & & & & & & 0,17 & 1,40 \\
\hline \multirow[t]{2}{*}{300} & 130 & 39000 & 1,40 & 54600 & 43500 & 11100 & & \\
\hline & & & & & & & 0,47 & 1,40 \\
\hline \multirow[t]{2}{*}{300} & 140 & 42000 & 1,40 & 58800 & 44899 & 13901 & & \\
\hline & & & & & & & 1,40 & 1,40 \\
\hline \multirow[t]{2}{*}{300} & 150 & 45000 & 1,40 & 63000 & 49099 & 13901 & & \\
\hline & & & & & & & 2,42 & 1,40 \\
\hline 300 & 160 & 48000 & 1,40 & 67200 & 56370 & 10830 & & \\
\hline
\end{tabular}

\section{CONCLUSIONS}

The production of forage (especially grain) in this region is limited, which is why the expenses for forage are the greatest in production for both products - milk and lamb growth.

The cost analysis indicated that it was lower in some of the farms, yet close to the sale price, while in the larger portion of the farms (in all three groups), it was higher.

The developed model for profit maximisation in the production of sheep's milk led us towards the following parameters: milk price of BGN 1.40 per litre and amount of produced milk between 42,000 and 45,000 litres, in which case the profit was maximal per both methods.

\section{REFERENCES}

1. Yanakieva, I. and Velev, St., 2006. Criteria for defining mountain less favored areas, Economics and Agriculture Management, 51, 2, 9-16, 2006.

2. Resolution by the European Parliament from September 23, 2008, Official Journal of the European Union C 8 E/49, 14 January $2010 . \quad$ eurlex.europa.eu/LexUriServ/LexUriServ.do?u ri=OJ:C:2010:008E:0049:0057...

3. Resolution by the European Parliament from June 23, 2011.

www.mzh.government.bg/.../Resolution_E P_23_06_2011.sflb.ashx

4. Angelova, V. et al., Agricultural Economics, V.T, Abagar, 1999, pp.211. 